\title{
The Radiant World of John Virgo
}

\author{
Robert E. Kohn
}

Published online: 20 July 2013

(C) International Atlantic Economic Society 2013

\begin{abstract}
John Virgo gave generously of himself and expected nothing in return. He inspired the same in others. The world has sadness as well as joy, but while he was here, he made it radiant.
\end{abstract}

Keywords Brazilian crisis · Double taxation - FDA · Medicare - Nobel prize - OPEC · John M. Virgo

I am honored by Katherine Virgo's request that I submit a paper on her beloved husband for this special issue and by her identification of me as "one of the few who were both involved with the organization and also a colleague of John's at Southern Illinois University at Edwardsville (SIUE)" (email 3/15/13). This has been the most difficult paper that I have ever written. I want it to be mostly about John, but it is mostly about me. In our relationship, he was always giving and I was always receiving. The main exception was when I told him that my primary care physician was located near his office in St. Louis; since he and Kathy just happened to be in need of a doctor, they both changed to her. The reason that this article is mostly about me and, at the same time, about John is that he was consistently in the foreground or the immediate background of many of the important phases of my professional life.

In the mid-1970s when John moved to SIUE, the natural place for him would have been in the Department of Economics, but given his overriding focus on developing his young society and journal, he chose the Department of Management. Both departments were in the School of Business, but management, as well as marketing, which was eventually joined to it, was an emblematic department and could offer the most support for John's extramural needs. It turned out to be a beneficial choice on his part for everyone involved. That the society and journal were located at SIUE surely added to our local economists' status when we submitted manuscripts to economic journals, for John had already begun to attract national attention, alluring some of the world's leading economists to participate on the Journal's board of editors and to serve as officers of the society and members of its executive committee. Three of the 25 presidents of the Society in the last quarter century had been Nobel

R. E. Kohn $(\bowtie)$

Southern Illinois University Edwardsville, Edwardsville, USA

e-mail: robert.kohn.49@post.harvard.edu 
laureates before they served, but it attested to John's prescience that three more became Nobel Laureates after.

It was a tragedy that John, in his prime at 69 , was struck down by gram negative bacterial meningitis. He had only one more week of oral chemotherapy and radiation therapy left to go in his battle with brain cancer and had every chance of surviving a full year thereafter, but his body was too immune-compromised to fight the infection.

\section{John's Contributions to Healthcare Economics}

The cause of John's premature death is all the more tragic because of his extensive scholarly contributions to the economics of healthcare. His last three books were Health Care: An International Perspective (1984), Exploring New Vistas in Health Care (1985), and Restructuring Health Policy: An International Challenge (1986). Of his 49 articles and chapters in books, 11 were on health care. Of the 52 papers presented at conferences, healthcare was the subject of 16 of them. David Ault, past Dean of the School of Business at SIUE, attributes John's interest in health care economics to his wife's scholarly achievements in that area, which is all the more to John's credit. When I suggested to Kathy that as "outstanding as your career has been, I suspect that his encouragement played a part in it" (email 12/10/12), she replied: "You are correct. He was always there for me, supporting me in whatever I chose to do. Life is not the same without him by my side" (email 12/23/12).

About the same time as John's death from bacterial meningitis, a specialty pharmacy-related meningitis outbreak occurred. This outbreak and the related policy debacles were made public in the appearance of Margaret A. Hamburg, M.D., Commissioner of Food and Drugs in the U.S. Department of Health and Human Services, before the Subcommittee on Oversight and Investigations of the U.S. House of Representatives on November 14, 2012. Included in her statement was some disturbing background information. In March 1992, the Agency had issued a Compliance Policy Guide delineating the FDA's enforcement policy on pharmacy compounding (the mixing of drugs to physician specifications), to which the compounding industry objected.

“. . . several bills were introduced, some with significant support, to limit the Agency's oversight of compounding. In May 1966, in a House Commerce Committee hearing on FDA reform legislation, FDA Commissioner David Kessler testified that the compounding provision being considered by the Committee was likely to encourage large scale manufacturing under the guise of pharmacy compounding, and could allow for potentially dangerous compounding of sterile products, leading to serious safety problems or death." (Hamburg 2012, 5)

The subsequent Food and Drug Administration Modernization Act of 1997, which addressed the FDA's authority over compounded drugs, exempted such drugs from the following three critical provisions of the act:

"the premarket approval requirement for 'new drugs'; the requirement that a drug be made in compliance with current good manufacturing practice; and the 
requirement that the drug bear adequate directions for use, providing conditions are met." (Hamburg 5)

Such brazen exemptions characterized the rejection of regulation that was growing among conservative congressmen. Abetted by present laws, Commissioner Hamburg charged that the New England Compounding Center in Framingham (NECC) "has repeatedly disputed [the] FDA's jurisdiction over its facility," noting that when the "Massachusetts Board of Pharmacy re-inspected NECC in 2011 [, ... it] found the facility to be "satisfactory"' (4). Based on my reading of Hamburg's statement, I would argue for a new rule, that any compounding pharmacy that ships "out of the state" as much as "5\% of [its] total prescriptions" should be subject to strict FDA authority (5). As the situation stands, there is a palpable conflict of interest at the state level that such a rule would eliminate.

\section{John Virgo Institutes the Anthology Section}

In the very first issue (November 1973) of the Atlantic Economic Journal, John introduced a promising new section based on his conviction that ". . . there is a substantial need to increase communication and share constructive viewpoints between economists. In addition to formal publication of full length articles, other avenues of less formal communication should be available. A small point may not be worthy of a formal paper but is important enough to warrant dissemination to colleagues. Research in progress may be of interest to other economists. A research approach ending in negative results needs to be shared to save others from similar pitfalls. The Anthology has been established to facilitate this form of communication. It will provide a means by which short manuscripts can quickly appear in the Journal with no formal referee process." (Virgo 1973)

I look on this innovation as another of the institutions that John kept building all his life. The last economics article that I published was in the Anthology section of the March 2007 issue of the Atlantic Economic Journal. With the writing of that article as background, I can better understand the meningitis debacle in the politicaleconomic context in which Commissioner Hamburg presented it. The fact that legislators insisted on exempting compounding pharmacies from three eminently reasonable requirements in the Food and Drug Administration Modernization Act of 1997 and that the New England Compounding Center's facility was given a "satisfactory" clearance when it was inspected by the Massachusetts Board of Pharmacy reinforced my argument in the Anthology article that "the benefits that lobbyists deliver are likely to be economically inefficient, wasteful and distortionary" (Kohn 2007, 116). The exorbitant election campaigns in this country make it almost necessary for elected officials to act in the interests of large contributors rather than the public at large. The low marginal tax rates on the highest incomes enable executives to keep more of the bloated salaries that lobbying excesses help such executives garner.

No other economics journal would have published such a speculative paper as this last one of mine. As to its ideological bias, this was before the rise of the NeoRepublicans, and I believed that most economists, brought up as I was in the public 
finance tradition of Richard Musgrave, would agree with me. It was ironic that Musgrave, whose greatest achievement was his three-part model of national government, served as president of the International Atlantic Economic Society during the presidency of Ronald Reagan, whose legacy lives on in the words of Grover Norquist: "I'm not in favor of abolishing the government. I just want to shrink it down to the size where we can drown it in the bathtub." Norquist is even better known for his unusual tactic for drowning the federal government: a public pledge not to raise taxes or reduce subsidies, which $95 \%$ of all Republican Congressmen signed prior to the 2012 election.

By the time I wrote my last Anthology paper, I had published my first five journal articles in literary criticism, using economic-type conceptual models to organize my thoughts. Literary critics were especially derisive of my application of Milton Friedman's approach. In fact, Friedman's approach worked for me. (see Moore 2012, 110)

\section{My Temporary Segue Back to Economics}

When new acquaintances learned of my background in economics and asked me to explain something in that area, it usually had to do with macroeconomics. I was quick to beg off with the excuse that I specialized in microeconomics, not macro-. However, when Neo-Republican economics came to the fore in the second Bush's second term, I could not believe the escalating paranoia over the national debt and redistributive justice. In graduate school, I was steeped in the public finance tradition of Richard Musgrave and presumed that only outlier economists would argue with his idealized division of national government into the allocation, distribution, and stabilization branches that took positivistic Keynesian economics to a normative level. Although I had presumed that my economics career was behind me, John Virgo's courageous publication of my 2007 Anthology piece on the economic excesses fostered by the flattening of marginal income tax rates prepared me for another temporary, but broader, segue back to economic activism.

In 2011, I published a book: Psychomachia or "The Fight for Mansoul: Making Moral Sense of Neo-Republican Economics". Whereas I once disqualified myself from answering questions on macroeconomics, I found myself taking issue with such prominent economists as Alberto Alesina, Silvia Ardagna, and Robert Barro (Kohn 2011, 53-55, 62-64). As soon as the book came out, I emailed John Virgo and broached the idea of asking my good friend, the brilliant microeconomist Ira Horowitz, to write a review of the book with the understanding that it would be published in one of John's journals. John obligingly said that I should see if Ira "is interested [and] if he agrees," that he would "follow up with a formal invitation to him" (email 11/16/11).

I may have gone too far in combining economics with literary satire because Ira was stymied when he received the book. "It's a pleasure to read," he said in an email dated 11/27/11, but:

"First, what I know about Roman Christian poets in general, and Prudentius in particular, would fit on the head of a perilously small pin, [...] Second, and despite the fact that in all likelihood I was a student in the first class that Musgrave taught when he came to M.I.T. in the fall of 1956, my expertise 
in fiscal policy would likely fill the remaining space on that pin head." (Horowitz 1)

Sadly for both of us, Ira had to bow out. With Ira, turning me down, I gave up on the review. I felt that John had already done more for me than I deserved, and I did not want to push him. Back in 1998, when I published Pollution and the Firm, the Atlantic Economic Journal no longer published book reviews, but John volunteered to publish one as a full length book review article. I was overjoyed by this, and my friend Jon Harford took on the writing with enthusiasm. His eight page article appeared in a special section, which carried the heading "Book Review Article", in the September 1998 issue of the Atlantic Economic Journal and was instrumental in my getting a Distinguished Visiting Professorship at Central Missouri State University. There is no way that I can separate my professional career from John's generosity.

\section{Meeting Abba Lerner and William Vickrey at the Ninth International Atlantic Economic Conference in Freeport/Lucaya, Bahamas in February 1980}

All I remember of the International Atlantic Economics Conference in the Bahamas in 1980 is the dream-like final day. Participants were invited to walk together on a trail through Freeport's Garden of the Groves, an 11 acre botanical park filled with entrancing plants, flowers, trees, and waterfalls. John may have seen to it that I and others had opportunities to briefly walk one-on-one with Abba P. Lerner, famous economist from England, émigré to the United States in 1937 and at that time, president of the International Atlantic Economic Society. Conference attendees also had the opportunity to walk one-on-one with William S. Vickrey, who would become president of the society 11 years later. My wife Martha got to walk the whole way with Dolly, the sparkling young woman whom we took to be Abba's wife. The two women bonded and Martha was happier than I remember her being in all our 58-years together. Martha died of breast cancer less than six weeks after John died. At first it hurts when something causes me to miss her, but remembering her in this dreamlike setting, so confident and happy, may help me when I need it. Only now that I have begun researching Lerner's life do I know that he was married to Alice Sendak, with whom he had twins and later divorced. Abba died in 1982, and my computer search reveals no second wife or Dolly. I assume she was his companion.

I too was on a high in the Garden of the Groves that day; in my first or second semester at Harvard in 1946, we studied Abba Lerner's Economics of Control: Principles of Welfare Economics as though it were the most important economics text ever written. It may well have been for me; from 1972 until 2004 my principal focus was on those marginal rates of substitution and of transformation he wrote about. It was not until 2004, with John's publication of my penultimate Anthology piece, was I able to rescue myself from "the Samuelson torture" (Kohn 2004, 69). Although I devoted my professional life almost exclusively to the welfare economics of air pollution control, I never realized until now that Lerner was my primary influence. Nor had I learned until now, from the Abba P. Lerner website of the online Concise Encyclopedia of Economics, that Lerner in 1934 published a clear 
diagrammatic exposition of international trade that everyone attributed to the 1948 paper by Samuelson, who of course acknowledged Lerner's priority.

My connection with Vickrey was equally strong. Back in June 1967, having decided to write my dissertation on air pollution control in the St. Louis airshed, I attended the Air Pollution Control Association meetings in Cleveland. The most important section for me was an invited paper by Vickrey entitled "Theoretical and Practical Possibilities and Limitations of a Market Mechanism Approach to Air Pollution Control." In the Bahamas, almost 13 years later, I was finally able to meet Vickrey and get to know him. Fortunately, I still had one of the mimeographed copies of his address that he had distributed at the conclusion of his Cleveland session. After extensive research, I was satisfied that it had never been published by him or anyone else. The year that Vickrey was president of the American Economic Association and the International Atlantic Economic Society, I revisited him at Columbia University in New York, got his permission to publish the 1967 paper, submitted it to Land Economics along with my own analysis of the paper's significance, and it was accepted almost immediately (Vickrey 1992). A few years later, something mysterious happened. A long distance phone call from Stockholm came in to the Department's office while I was in class, asking for reprints of my Vickrey articles, which I sent. Not long after the announcement that he had won the Nobel prize in 1996 did it occur to me that some Nobel committee judge may have used the reprints in building a case for Vickrey. I would have loved to call and congratulate him, but to everyone's shock, he died 3 days after the award was announced.

I regret whatever I did wrong or did not do right in satirizing Neo-Republican morality in terms of Prudentius' fifth century Virtues and Vices, because the book contains original ideas that I wanted publicized. Kathy has given me the opportunity to do it here, and knowing John's words on economists' sharing constructive viewpoints, I do believe that he would be happy she has done so. First, Neo-Republicans mistakenly insist that any increase in the marginal income tax rate on top earners will necessarily diminish incentive and reduce national output. In the late 1950s, my earnings as a traveling salesman selling low-priced little girls' shoes produced by Inland Shoe Manufacturing Company in southeast Missouri put me in a marginal income tax bracket of $72 \%$. Because I made only 28 cents on the marginal dollar of income, I realized it could be in my interest to lower our rate of commission on sales from $5 \%$ to $3 \%$. This permitted us to put more quality into our shoes, sell more of them, and make my job easier. Moreover, the two younger salesmen and I were able to sell the next season's capacity sooner, giving us more time at the St. Louis office to style and write specs for the next season's line, which was my responsibility. This enabled me to travel less and be home with Martha and my two, and then three, young sons. When I left the company in 1966 for graduate degrees in economics at Washington University, the work force exceeded many hundreds of people. I credit the high marginal income tax rate for indirectly facilitating this growth (Kohn 2011, 31-33).

Neo-Republicans claim that the taxation of shareholder dividends from corporations that already pay a tax on income is double taxation. Accordingly, and sadly for government revenue, the tax on dividends has been slashed. This, more than any change in the tax code, explains why secretaries pay higher marginal tax rates than 
their wealthy bosses. The argument is often reinforced by the notion that corporations are legally persons, and if the corporate "person" pays the tax, the dividend-receiving, share-holding persons should not pay any of it again. In fact, these two persons are hardly equivalent. The real, share-owning persons have the enormous protection of limited liability; if the corporation goes bankrupt, the creditors cannot sue them for what their corporation owes. Eight years ago, I bought stock in a company that owns natural gas pipelines connecting producers to wholesale distributors. Shortly thereafter, I received the company's prospectus detailing its various risks. To my astonishment and chagrin, one of these was stockholder liability for environmental damage judgments against the company. I sold that stock quickly and have been mindful ever since that corporations, though the law may treat them as persons, are privileged in a way that real persons are not. Given that corporations pay a tax on their income, as indeed they should, the generally smaller amount of income that they disperse as dividends to shareholders should be taxed, to compensate for the limited-liability that protects shareholders from judgments that could be many times the size of the dividend (Kohn 2011, 33-34).

My career as an environmental economist more than 20 years ago came to mind when Tom Fournier, the Vice-President of Engineering in the Tucson office of an automotive-emission-control systems company, read my book on Neo-Republican morality and then sent me his chapter from the recently published second edition of a prominent textbook on environmental ethics. Fournier's work took him to Sao Paulo, Brazil where he witnessed the civil unrest in a country hampered by an unfair distribution of income and wealth across economic classes. He wrote that

“. . . our cab driver instructed me to remove my elbow from its perch on the window sill and roll up my windows. He explained that, at stop lights, thieves would sometimes pin the arm of an unsuspecting passenger to the sill using a knife - this to ensure cooperation while they removed wrist watches or jewelry." (Fournier 2011, 590-91)

A few days after receiving the chapter, there was a related article in The New York Times by Simon Romero which began:

"A wave of arson attacks is spreading across a state in Southern Brazil, largely targeting police installations, public buses and even the homes of prison officials in a region that has traditionally ranked among the country's safest. Since the end of January, there have been about 80 attacks in more than 20 cities throughout Santa Catarina, a relatively prosperous state of 6.3 million people." (Romero 2013, A9)

Brazil is one of the most industrialized countries in South America, and it is not surprising that Santa Catarina is relatively prosperous. It appears that civic violence in a country depends not on GNP per capita but on the distribution of income and wealth across income classes. In "Brazil, the richest quintile received more than 30 times more than the poorest quintile," as compared to "high-income countries [of] the developing world" where "the ratio averaged about 6:1" (World Bank 2004, 1). Unlike Douglas Holtz-Eakin, president of the American Action Forum, who worried on This Week with Christiane Amanpour that the United States is "headed straight toward a Greek crisis" (Kohn 2011, 56), I worry that we are headed toward a Brazilian crisis. A Greek crisis is easily handled in the United States, since our debt 
is in dollars and not euros, but a Brazilian crisis would be worse in the United States than in Brazil because of the enormously bloated supply of privately owned attack weapons here (See Kohn 2011, 65-66). One wonders if the recent shootings of prosecutors in Texas are a harbinger of Brazil. I had that in mind when I made the strongest statement of all in my book:

"So great is inequality of income in the United States that we would surely be experiencing volatile extremes of social turmoil if it weren't for Social Security, Medicare and Medicaid. Most families have or have had members in one or more of these programs and appreciate that they are federally subsidized." (Kohn 2011, 48)

I would welcome research on such attitudes among people in our society who are most likely to be alienated.

\section{Concluding Remarks}

Writing this paper has been a life-changing experience. The world of people like John Virgo who give and give is more like the world of literature that I have turned to than is the political world of quid pro quo or the economic world of mutually benefiting exchange. In Marilynne Robinson's Gilead, there are characters that give much and take little (Kohn 2012). I remember asking Bill Vickrey how it happened that he was president of the AEA and the IAES at the same time, and he said that he had not thought much about that. I took him at his word, but now I think he was a goodhearted man and did not want to turn his friend John down. John was the kind of person to whom people took pleasure in giving. He in turn liked giving to people who needed him as I certainly did; again, and again, and again. Now I realize why John went to the Department of Management rather than the Department of Economics. He knew that he could do more for them. His curriculum vita is full of papers coauthored by people in management and marketing.

I sensed Abba Lerner's joy in giving to John the article about himself on the Concise Encyclopedia of Economics website. It must have been about the time of the Bahamas conference that Lerner came up with a brilliant plan for breaking OPEC, which had been so obdurate during the 1970s. According to the website,

"Lerner advocated that the United States and other governments of consuming countries impose a $100 \%$ excise tax on the difference between OPEC's price and the pre-OPEC price adjusted for inflation. In 1980 OPEC charged 26 dollars for a barrel of oil. The pre-OPEC price adjusted for inflation was six dollars. Therefore, at that price, the tax would have been $100 \%$ of $26-6$, or 20 dollars. Lerner's plan, if followed, would have caused the price to consumers to rise two dollars every time OPEC raised its price one dollar. More important, it would have caused the price to fall by two dollars every time OPEC lowered its price by one dollar. Lerner's thinking, which was absolutely watertight, was that this plan would double consumers' elasticity of demand, causing them to demand less oil at higher prices and thus reduce the strength of the cartel." 
This article, the website revealed, was published in Volume 8, No. 3 of the Atlantic Economic Journal. That was in the fall of 1980, seven or eight months after the Bahamas conference. Lerner could have published that article in a journal with a higher impact factor, but chose to allow John to publish it in the Atlantic Economic Journal.

John Virgo gave generously of himself and expected nothing in return. He inspired the same in others. The world has sadness as well as joy, but while he was here, he made it radiant.

\section{References}

Fournier, T. (2011). “Air pollution abatement strategies.” In D. Schmidtz \& E. Willott (Eds.), Environmental ethics, what really matters, what really works, second edition. Oxford University Press.

Hamburg, M.A. (2012). "The fungal meningitis outbreak: Could it have been prevented." Statement to the Subcommittee on Oversight and Investigations, U.S. House of Representatives. http://www.fda.gov/ NewsEvents/Testimony/ucm327664.htm.

Kohn, R. E. (2004). The Samuelson torture. Atlantic Economic Journal, 32.1, 69.

Kohn, R. E. (2007). Inflated executive salaries, lobbying excesses, and exorbitant election campaigns. Atlantic Economic Journal, 35.1, 115-116.

Kohn, R. E. (2011). Psychomachia or "The Fight for Mansoul": Making moral sense of neo-republican economics. Brentwood: Mira Digital Publishing.

Kohn, R. E. (2012). Radiance and secrecy in Marilynne Robinson's Gilead. Brentwood: Mira Digital Publishing.

Moore, S. (2012). "Robert E. Kohn. New close readings of the crying of Lot 40, Brentwood, MO: Mira Digital Publishing, 2011. <www.mirasmartshop.com/Kohn-Robert-E_c_233.html > 216 pp. Paperback, \$10.49." Style 46.1:110-112.

Romero, S. "Inmates seen as guiding arson attacks in Brazil." New York Times, February 9, 2013, A9.

Vickrey, W. S. (1992). Theoretical and practical possibilities and limitations of a market mechanism approach to air pollution control. Land Economics, 68.1, 1-6.

Virgo, J. M. (1973). Anthology. Atlantic Economic Journal, I.1, 72.

World Bank (2004). Beyond economic growth student book, second edition. Chapter V. Income Inequality. $<$ http://www.worldbank.org/depweb/english/beyond/global/chapter5.html >. 